\title{
CORRESPONDENCE
}

\section{Alice Economics}

SiR,-We feel that you have failed to understand the issues involved in continued economic growth (Nature, 234, 2 ; 1971). It is undeniable that pollution has accompanied economic growth. It may be that economic resources are required to stem the effects on the environment, but before this can be brought about a whole new political atmosphere is needed: our economic efforts must be redirected. Much of the economic effort in modern industrialized communities, such as the EEC, is invested in the production of non-essential consumer goods, aerospace and defence technologies, and other areas where raw materials are consumed almost unthinkingly and where attendant pollution problems are solved, if at all, only as an after-thought.

The industry of the future should be one in which a much greater proportion of the materials used will already have been recycled many times. It should be manufacturing items which are more directly applicable to the world's problems, such as medical goods, birth control devices, agricultural materials, and housing materials. The need for these goods is mainly in poorer countries. The required revolution in the foreign aid and internal economic policies of the rich countries will not be achieved without a radical change in political atmosphere, and we share Professor Scorer's disappointment that no mention of these points was made in the EEC debates.

It is indeed no accident that the richest nation is the most worried about pollution, since it has considerably more than the rest of us, as a result of greater economic advance, and is feeling the effects earlier than most. In pollution terms, and in terms of per capita use of natural resources, one American has a far greater impact than, for example, one Indian. Also, many American citizens are aware of the continuing failure of their political leadership to deal with these problems, and do not share your blind faith that all will turn out right in the end.

What you ignore is that we live in a world which has only a limited quantity of raw materials and can only support a finite population. The plain fact is that the world could not support even its present population if everyone shared the American standard of living: if we wish everyone to be decently fed and housed, somebody has to be prepared to give. That includes us.

Yours faithfully,

\section{J. Bolton \\ J. E. CORDWELl}

154 Redland Road,

Bristol BS6 6TD

\section{Alice Economics}

SIR,-I find the editorial attitude expressed in Professor Scorer's letter to The Times distressing; and, worse, bigoted. If he is irresponsible in his "environmentalist" attitudes, so indeed are you with your "growth is a prerequisite to improvement" attitude. Do you have a connexion with economists? It appears to me that only they of our ideological dinosaurs continue to put all their eggs in the long since worn out basket of required economic growth via an expanding population. Surely economic growth can also be achieved with a static or even a decreasing population?

Overall there is perhaps only one obvious fact, one which you choose to ignore, and which is the basis of Professor Scorer's letter. This is the need for a fundamental change of some sort. To a mathematician, or indeed any logically inclined person, the exponential curve of population growth can have only one answer, and that is change. The change may be controlled or cataclysmic, but change there will be.

Your comparison of our small and already overcrowded island with the USA (some four times the population in around forty times the area) is ridiculous. That country, with presentday technology, is already capable of feeding its estimated population for the year 2000 and beyond, while our population has already outgrown our own food supply. Indeed, even India, with around eight times the population in twelve times the area, is better placed; when the pressures arise, we shall be among the first to experience them.

Your dismissal of the pollution problem on the grounds of lack of specificity is irresponsible. More worrying is your lack of awareness that the decrease in fish landings to which you refer is itself a form of pollution. Pollution by taking needs to be considered with pollution by dumping.
The Kansas dust-bowls were not produced by the dumping of dust.

Your patronizing attitude to our poorer neighbours must irk them in the extreme. Must they continually rely on aid based on a fraction of our growth? Again a mathematically (and historically) unacceptable model in the long term.

May I say finally that I already find the pressures of today's society bearable only with difficulty, and that I take Professor Scorer's ideas seriously enough to wonder if I wish to take part in your rich and sterile utopia with its increasingly (and necessarily) controlled overpopulation. Yours faithfully,

\section{A. Ellis}

Westfield College,

University of London,

London NW3

\section{Ethics for Authors}

SIR,-As editors of a monograph series published by a well known university press, we have each had recently the following experience. A competent scientist asks us to consider publishing a book which he has on hand. We reply showing interest, and negotiations begin, involving the assessment of a synopsis and sample chapters, a check on the existing literature, and advice to the press to publish. Improvements of style and content are suggested to the author, and a formal contract is prepared. This is a lengthy procedure and may take many months. We are then told that the finished book has been accepted by another publisher, with whom, in fact, the author was simultaneously negotiating.

In the selling of a house such conduct is usually regarded as dishonourable, if not quite actionable. In the jungle of commercial publishing one must, no doubt, be prepared for such dishonesty. But in the production of specialized scholarly works this is unethical behaviour, not at all in the interests of authors themselves.

It is true that we are paid as editors in proportion to the success of the books that we get into print. Some unscrupulous editors and publishers make a quick profit by accepting every manuscript, without question or revision and wax rich on high-priced sales to libraries. But most scholarly editors do not do this sort of job solely for monetary 
gain: they regard their labour as a general service to the scholarly community, to maintain high literary and scientific standards, for the benefit of their colleagues as authors and as readers.

Our complaint is at the selfish and frivolous waste of our professional time and effort in the name of "free competition". Not nearly enough trouble is taken by most scientists to improve the quality of the books they must read: it is scandalous that the little we do should be spent thus fruitlessly. It is poor consolation, incidentally, to observe afterwards that the author has not hesitated to benefit (without acknowledgment) by the improvements we have proposed.

We also believe that the credibility of scientific publications depends upon an agreed and orderly framework, in which well qualified editors and reputable publishers respect themselves and one another. The margins of technical book publishing are not so elastic as to allow wide variations in the real terms that can be offered to authors. The ultimate financial return on a book depends on much more imponderable factors than the apparent royalty percentage or the quality of the burgundy at a tax deductible lunch. A good book can easily be published and an author does much better by bargaining hard and honestly with almost any single good publishing house than by "shopping around".

Some people do not seem to have thought this out, and fall for the fast buck. Let us spell it out to them. They know well enough that they must not submit the same research paper simultaneously to two different journals. We suggest that the behaviour here reported must be considered a comparable breach of the unwritten ethical code of the scientific community.

Yours faithfully,

M. M. WOOLFSON

J. M. ŹIMAN

H. H. Wills Physics Lahoratory,

Royal Fort,

Tyndall Avenue,

Bristol BS8 ITL

\section{Viral DNA Integration}

SIR,-_In a review article "Vintage Year for Tumour Virology" (Nature, 233, 28; 1971) John Tooze states: "and the recent experiments of Wall and Darnell (Nature New Biology, 232, 73; 1971) dispel any doubts about the integration of polyoma (actually SV 40) virus DNA into host cell DNA". Recent experimental evidence throws new light on this situation (Gelb et al., J. Mol. Biol., 57, 219; 1971). Because of it, there is to my knowledge no published evidence which conclusively demonstrates the integration of SV 40
DNA into the DNA of the transformed host cell. Gelb et al. have recently shown that host specific SV 40-like sequences exist in non-transformed cell green monkey and mouse DNAs. About one-half copy of host specific SV 40-like sequence is present in each cell. Published experiments designed to demonstrate the integration of SV 40 into transformed cell DNA have relied on the reaction of SV 40 C-RNA (RNA made in vitro from SV 40 DNA) with transformed cell DNA which had a molecular weight much higher than SV 40 DNA (Sambrook et al., Proc. US Nat. Acad. Sci., 60, $1288 ; 1968)$. It was assumed that any reaction of C-RNA was with virus specific SV 40 sequences, which had been integrated into the host cell DNA. However, the existence of host specific SV 40-like sequences in DNA from transformed cells complicates the interpretation of these data. It is not known whether the C-RNA reacted with host or virus specific SV 40-like sequences. The interpretation of Sambrook et al., that SV 40 DNA is integrated, rests entirely on the greater degree of reaction of SV 40 C-RNA with high molecular weight SV $3 \mathrm{~T} 3$ cell DNA than with PY 3T3 high molecular weight DNA. This result could be the consequence of: $(a)$ the integration of virus specific SV 40 sequences in the host DNA, or (b) the differential replication in SV 3T3 cells (and not in PY 3T3 cells) of the chromosomes which contain the host specific SV 40-like sequences.

The data of Lindberg and Darnell (Proc. US Nat. Acad. Sci., 65, 1089; 1971) and Wall and Darnell are also difficult to interpret for the same reason. It is not known whether the large RNAs they detect, which contain both SV 40like and host specific sequences, arose from virus specific SV 40 sequences or from the host specific SV 40-like sequences which are present in non-transformed cells.

In summary, I do not believe that the virus DNA integration into transformed cell DNA has been proven.

Yours faithfully,

David E. Kohne

Biophysics Section,

Department of Terrestrial Magnetism, Carnegie Institution of Washington, Washington DC 20015

\section{Library Optimum}

SiR,--In his recent article ${ }^{1}$ B. C. Brookes propounds an ingenious mathematical framework to determine which periodical volumes a library should hold. $\mathrm{He}$ is careful to point out that the selection will need regular review and revision, in case the value of the ageing factor $a$ or the contents of the Bradford set change from year to year. There is as yet very little experimental evidence on the consistency of either. Such limited evidence as there is suggests that the ageing factor is reasonably constant. But the position of the Bradford set is less satisfactory. The Nature Conservancy librarians (J. M. Weingott and S. M. Penny, unpublished) have lent me a list of titles cited in the Journal of Ecology three or more times in 1955-56, and a similar list for 1965-66. There are 150 periodical titles in the two lists, but only forty-two $(28 \%)$ appear in both. Of the thirty-three titles cited nine or more times in either year, only eight $(25 \%)$ attained that level in both, and twelve were cited less than three times in the other year. The Kendall rank correlation coefficient between the two years is 0.18 and not significant.

There is another major practical problem. The article assumes that the data analysed to obtain ageing or utility factors and Bradford sets are valid parameters of the relative value of the literature to the readers. There is no mention of the type of data to use. The reader who sought guidance from the earlier literature cited would find practical techniques described in which analyses of citation frequencies are used to calculate utilities discussed in terms of library use. Krauze and Hillinger ${ }^{2}$ have discussed the difference between citations in one article and future citations to that article. Their work implies a more complex relation between $a$ and $u$ than Brookes suggests. In any case, the validity of citations for forecasting library consultations remains unproven, and there are prima facie reasons why the relationship is not necessarily close. For example, one item in a list of references is often intended to lead to a chain of earlier papers. Again, each citation represents an author's selection from a wider group most of which he has consulted in a library. In neither case is there any inherent reason for similarity of age distribution or of pool of titles between the list of citations and the items read by the author or his readers.

Most of the practical studies of citations or library use have so far been based on the relation between frequencies and age or title, without considering the number of items available for reference. But, to be useful as parameters of the relative value to scientists of groups of volumes, the data must be presented as the number of references per available item, and not as the numbers from groups of differing size. The need to correct "obsolescence rates" for the fact that there is much less of the older literature to cite or read is becoming generally recognized. When the appropriate corrections are made, it has been shown ${ }^{3}$ that in some library contexts the older literature can be more heavily used than the younger. In all calculations based on Brookes's utility concept it is therefore essential that the utility factor $u$ be derived from an ageing factor $a$ repre- 